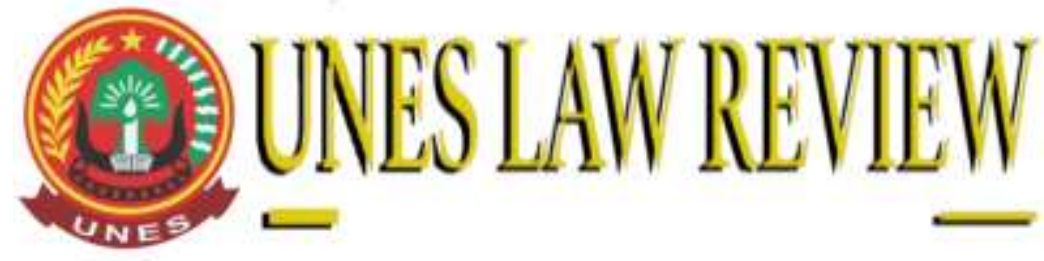

$+6282287504359$

$+6282287504359$

https://review-unes.com/

uneslawreview@gmail.com

DOI: https://doi.org/10.31933/unesrev.v3i3

Diterima: 15/12/2020, Diperbaiki: 24/05/2021, Diterbitkan: 26/05/2021

\title{
PERLINDUNGAN HUKUM BAGI MASYARAKAT DALAM PELAKSANAAN PEMBATASAN SOSIAL BERSKALA BESAR DI KOTA AMBON
}

\author{
1) Andress D. Bakarbessy, ${ }^{2)}$ Miracle Soplanit, ${ }^{3)}$ Saartje S. Alfons \\ 1) - 3) Universitas Patimura, Ambon, Maluku, Indonesia \\ Corresponding Author: Andress
}

\section{ABSTRACT}

The implementation of the PSBB in the city of Ambon has received various criticisms from the public, there have been various actions by the community that have disobeyed the PSBB guardian, as well as problems with law enforcement by law enforcement officials. The purpose of the study was to examine and analyze the effectiveness of the implementation of PSBB in Ambon City and to examine and analyze legal protection for the people of Ambon City in implementing $P S B B$. The research method used is normative legal research. The results of the study show that: 1) The effectiveness of PSBB in Ambon city has not been implemented to its full potential. 2) legal protection for the people of Ambon city is more focused on enforcement (repressive) efforts than preventive prevention efforts.

Keywords: Legal Protection, Large-Scale Social Restrictions

\section{ABSTRAK}

Pelaksanaan PSBB di kota ambon mendapat berbagai kritikan dari masyarakat, adanya berbagai tindakan masyarakat yang tidak menaati perwali PSBB, maupun masalah penegakan hukum oleh aparat penegak hukum. Tujuan penelitian untuk mengkaji dan menganalisis efektivitas pelaksanaan PSBB di Kota Ambon dan untuk mengkaji dan menganalisis perlindungan hukum bagi masyarakat Kota Ambon dalam pelaksanaan PSBB. Metode penelitian yang digunakan adalah penelitian hukum normatif. Hasil penelitian menunjukan bahwa: 1) Efektivitas PSBB di kota ambon belum dilkasanakan secara maksimal. 2) perlindungan hukum bagi masyarakat kota ambon lebih difokuskan pada uapaya penegakan (represif) dibandingkan dengan upaya pencegahan preventif.

Kata Kunci: Perlindungan Hukum, Pembatasan Sosial Berskala Besar 


\section{PENDAHULUAN}

Dunia saat ini berada dalam kondisi darurat penyebaran virus disease covid- 19 sejak pertama kali ditemukan di Wuhan China di akhir tahun 2019 dan secara cepat menyebar keseluruh dunia, termasuk Indonesia yang melalui Presiden Jokowi pada tanggal 2 Maret 2020 mengumumkan pasien pertama COVID-19 di Indonesia.

Dengan adanya penyebaran Covid-19 yang terus meningkat dan telah berimplikasi pada semua aspek kehidupan, maka diperlukan upaya percepatan penanggulangan Covid-19 dengan langkah-langkah cepat, fokus, terpadu dan sinergis antar santuan pemerintahan di tingkat daerah yakni antar Pemerintah Provinsi dan Kabupaten/Kota termasuk keterlibat stakeholders dan seluruh lapisan masyarakat.

Berdasarkan hal tersebut maka berbagai kebijakan pemerintah dibuat untuk mencegah penyebaran yang lebih luas agar jumlah korban terinfeksi dapat ditekan. langkah-langkah antisipasi, termasuk ketegasan dalam memastikan penyebaran virus corona tidak bertambah untuk mengendalikan penyebaran virus corona, diantaranya:

1. Social Distancing dengan mencegah orang sakit melakukan kontak dekat dengan orangorang untuk mencegah penularan melalui imbauan pemerintah;

2. Karantina, baik itu karantina rumah (mandiri) maupun karantina wilayah; dan

3. Pembatasan Sosial Berskala Besar (PSBB);

Berbagai kebijakan tersebut didasarkan pada Keputusan Presiden Nomor 11 Tahun 2020 tentang Penetapan Kedaruratan Kesehatan Masyarakat Corona virus Disease 2019 (Covid-19), serta menetapkan Peraturan Pemerintah Nomor 21 Tahun 2020 tentang Pembatasan Sosial Berskala Besar Dalam Rangka Percepatan Penanganan Corona virus Disease 2019 (Covid-19), dan Peraturan menteri kesehatan Nomor 9 tahun 2020 tentang Pedoman Pembatasan Sosial Berskala Besar dalam rangka Percepatan Penanganan COVID-19 penyebaran Corona Virus Disease 2019 (COVID- 19).

Dalam Pertimbangan huruf a Permenkes No 9 tahun 2020 disebutkan bahwa jumlah kasus dan/atau jumlah kematian telah meningkat dan meluas lintas wilayah dan lintas negara dan berdampak pada aspek politik, ekonomi, sosial, budaya, pertahanan dan keamanan, serta kesejahteraan masyarakat di Indonesia.

Kota Ambon di Provinsi Maluku merupakan salah satu daerah di Indonesia yang telah mendapat persetujuan menerapkan Pembatasan Sosial Berskala Besar (PSBB) di Kota Ambon oleh Menteri Kesehatan Republik Indonesia berdasarkan keputusan Nomor HK.01.07/MENKES/358/2020 tentang Penetapan Pembatasan Sosial Berskala Besar di Wilayah Kota Ambon, Provinsi Maluku dalam rangka percepatan penanganan Corona Virus Desease 2019 (COVID- 19).

Alasan diajukannya PSBB oleh Pemerintah Kota Ambon karena telah ditetapkannya kota ambon sebagai zona merah virus corona oleh Kementerian Kesehatan. Kota Ambon dinilai sangat berisiko karena wilayahnya yang kecil dan padat, serta adanya keterbatasan sarana kesehatan dan tenaga medis. 
Berdasarkan hal tersebut maka untuk memberikan perlindungan bagi masyarakat kota ambon terkait dengan penyebaran virus covid 19 maka Pemerintah daerah kota (Pemkot) Ambon melaksanakan pembatasan sosial berskala besar melalui peraturan walikota ambon, diantaranya melalui Peraturan Walikota Ambon Nomor 18 dan 19 Tahun 2020 Tentang Pelaksanaan Pembatasan Sosial Berskala Besar Dalam Penanganan Corona Virus Disease 2019 (COVID-19) di Kota Ambon, Peraturan Walikota Ambon Nomor 20, 23 dan 26 tahun 2020 Tentang Pelaksanaan Pembatasan Sosial berskala Besar Pada Masa Transisi Menuju Masyarakat Sehat, Aman Dan Produktif Di Kota Ambon.

Berbagai ketentuan tersebut menjadi dasar bagi pemerintah kota ambon untuk memberikan perlindungan bagi masyarakat kota ambon ditengah penyebaran virus corona 19 melalui pelaksanaan PSBB. Menurut Philipus M. Hadjon bahwa perlindungan hukum berarti adanya tindakan untuk memberikan pertolongan kepada subjek hukum melalui sarana aparatur penegak hukum.

Sementara itu setiono menyatakan bahwa perlindungan hukum adalah tindakan atau upaya untuk melindungi masyarakat dari perbuatan sewenang-wenang oleh penguasa yang tidak sesuai dengan aturan hukum, untuk mewujudkan ketertiban dan ketentraman sehingga memungkinkan manusia untuk menikmati martabatnya sebagai manusia.

Dengan demikian keberadaan perwalikota ambon yang berkaitan dengan PSBB adalah untuk mengatur lalu lintas kepentingan masyarakat dalam kondisi penyebaran virus covid 19 serta untuk melindungi masyarakat dari tindakan penguasa yang tidak sesuai dengan ketentuan hukum yang terkait dengan pelaksanaan PSBB.

Dalam praktiknya PSBB yang diberlakukan di kota ambon menimbulkan kontradiksi dalam penerapannya, misalnya adanya larangan membuka tempat usaha selain untuk menjual bahan kebutuhan pokok dan kebutuhan sehari-hari sesuai Pasal 34 dan 35 Peraturan Walikota Ambon Nomor 18 Tahun 2020 Tentang Pelaksanaan Pembatasan Sosial Berskala Besar Dalam Penanganan Corona Virus Disease 2019 (COVID-19) di Kota Ambon. Dalam Pelaksanaannya menurut pedagang pakaian di Pasar Mardika bahwa tempat usaha di Pasar Mardika di tutup sedangkan di beberapa tempat usaha pakaian di wilayah tertentu di Kota Ambon tidak ditutup.

Sementara itu, menurut pelaku usaha di salah satu Plaza di Kota Ambon bahwa PSBB mengatur jam berjualan mulai pukul 08.00 pagi hingga pukul 20.00 malam sebagaimana diatur dalam Pasal 36 huruf a angka 3 Peraturan Walikota Ambon Nomor 18 Tahun 2020 Tentang Pelaksanaan Pembatasan Sosial Berskala Besar Dalam Penanganan Corona Virus Disease 2019 (COVID-19) di Kota Ambon, sementara surat edaran Sekretaris kota Ambon mengatur bahwa Plaza di Kota Ambon tutup total, hal ini menimbulkan kebingungan bagi masyarakat. Berdasarkan hal tersebut maka penelitian ini bertujuan untuk mengkaji perlindungan hukum bagi masyarakat dalam pelaksanaan PSBB di Kota Ambon.

\section{METODE PENELITIAN}

Metode penelitian yang akan digunakan dalam penelitian ini adalah penelitian hukum normatif, yakni suatu penelitian yang terutama mengkaji ketentuan-ketentuan hukum positif, asas-asas hukum, prinsip-prinsip hukum maupun doktrin hukum guna menjawab isu hukum yang 
dihadapi. Pendekatan masalah yang digunakan dalam penelitian ini adalah pendekatan peraturan perundang-undangan (statute approach) dan pendekatan konseptual (conceptual approach. Sumber bahan hukum dalam penelitian ini adalah sumber bahan hukum primer, sumber bahan hukum sekunder dan tertier.

\section{HASIL DAN PEMBAHASAN}

\section{Pelaksanaan Pembatasan Sosial Bersakala Besar di Kota Ambon}

Pelaksanaan pembatasan social berskala besar (PSSB) di Kota ambon memberikan dampak yang cukup besar bagi kehidupan masyarakat di Kota Ambon, hal ini disebabkan karena dengan adanya PSBB maka adanya pembatasan terhadap berbagai aktivitas yang dilakukan oleh masyarakat.

Pelaksanaan PSBB dilakukan dengan didasarkan pada:

1. Peraturan Walikota Ambon Nomor 18 Tahun 2020 Tentang Pelaksanaan Pembatasan Sosial Berskala Besar Dalam Penanganan Corona Virus Disease 2019 (COVID-19) di Kota Ambon, pada tanggal 19 Juni 2020

2. Peraturan Walikota (Perwali) Nomor 19 Tahun 2020 tentang Perubahan atas Peraturan Walikota Ambon Nomor 18 Tahun 2020 Tentang Pelaksanaan Pembatasan Sosial Berskala Besar Dalam Penanganan Corona Virus Disease 2019 (COVID-19) di Kota Ambon, pada tanggal 6 Juli 2020

3. Peraturan Walikota Ambon Nomor 20 tahun 2020 Tentang Pelaksanaan Pembatasan Sosialberskala Besar Pada Masa Transisi Menuju Masyarakat Sehat, Aman Dan Produktif Di Kota Ambon, pada tanggal 20 Juli 2020

4. Peraturan Walikota Ambon Nomor 23 tahun 2020 Tentang Perubahan Atas Peraturan Walikota Ambon Nomor 20 Tahun 2020 tentang Pelaksanaan Pembatasan Sosialberskala Besar Pada Masa Transisi Menuju Masyarakat Sehat, Aman Dan Produktif Di Kota Ambon, pada tanggal 3 Agustus 2020

5. Peraturan Walikota Ambon Nomor 26 tahun 2020 Tentang Perubahan Kedua Atas Peraturan Walikota Ambon Nomor 20 Tahun 2020 tentang Pelaksanaan Pembatasan Sosialberskala Besar Pada Masa Transisi Menuju Masyarakat Sehat, Aman Dan Produktif Di Kota Ambon, pada tanggal 17 Agustus 2020

6. Peraturan Walikota Ambon Nomor 36 tahun 2020 Tentang Perubahan Ketiga Atas Peraturan Walikota Ambon Nomor 20 Tahun 2020 tentang Pelaksanaan Pembatasan Sosial berskala Besar Pada Masa Transisi Menuju Masyarakat Sehat, Aman Dan Produktif Di Kota Ambon, pada tanggal 26 Oktober 2020

Dengan berdasarkan berbagai Perwali tersebut pelaksanaan PSBB di kota ambon dilaksanakan sejak tanggal 19 juni 2020. Sejak awal pelaksanaan PSBB di kota ambon mendapat berbagai kritikan dari masyarakat, adanya berbagai tindakan masyarakat yang tidak menaati perwali PSBB, maupun ketidak tegasan aparat penegak hukum dalam menegakan aturan PSBB.

Salah satu pengamat hukum di kota ambon menyatakan bahwa implementasi PSBB di kota ambon perlu dilakukan evaluasi terkait dengan keberadaan pos-pos chek point yang 
ditempatkan di beberapa lokasi di kota ambon sebaiknya itu ditiadakan, karena tidak maksimal dan mengeluarkan anggaran yang besar, terkecuali pos-pos chek point yang ditempatkan di batas administrasi kota ambon dengan kabupaten Maluku tengah.

Selain itu, persoalan yang perlu mendapat evaluasi dalam pelaksanaan PSBB di Kota Ambon adalah terkait dengan sanksi yang diberikan bagi yang tidak menggunakan masker. Dimana, ada perbedaan yang sangat menyolok dari penerapan sanksi itu. "Bayangkan yang berbocengan dan tidak menggunakan masker dikenakan sanksi Rp.50 ribu tetapi bagi pedagang yang tidak gunakan masker sanksinya Rp.250 ribu hingga Rp.500 ribu.

Dalam berbagai pengamatan di masyarakat dapat dijumpai bahwa di awal pelaksanaan PSBB di Kota ambon banyak warga yang beraktivitas di luar rumah tanpa memakai masker dan tidak menjaga jarak terutama di tempat-tempat umum, seperti di Pasar Mardika kota Ambon, masih ada pedagang yang tak memakai masker dan membuka toko melewati waktu yang ditetapkan. Warga juga masih melanggar jam malam yang ditetapkan di Kota Ambon, dimana masih banyak warga yang berkumpul setelah pukul 23.00 WIT

Sementara itu, keberadaan aparat dalam menegakan aturan PSBB juga sering dipertanyakan, misalnya terkait dengan aktifitas pedagang di Ambon Plaza dan sekitarnya, hingga ke kawasan A.Y Patty yang secara paksa ditutup tanpa alasan yang jelas. Padahal sesuai Perwali, bahkan telah disosialisasikan dalam bentuk spanduk dan dipajang di sejumlah titik bahwa aktifitas pertokoan dan mall dimulai pukul 08.00-20.00 WIT, bahkan hanya kawasan tertentu yang dipaksa untuk ditutup.

Hal tersebut menunjukan bahwa pelaksanaan PSBB belum efektif karena aktivitas masyarakat di ruang publik juga belum dapat dikendalikan dalam menatati protokol kesehatan, misalnya mengurangi kerumunan, jaga jarak, dan pakai masker, serta masih terdapat rumusan norma sanksi bagi yang tidak memakai masker dalam perwali kota ambon tentang PSBB yang masih menimbulkan pertentangan dalam pelaksanaannya.

\section{Perlindungan Hukum Bagi Masyarakat Dalam Pelaksanaan PSBB di Kota Ambon}

Penjelasan UUD 1945 sebelum amandemen menyatakan bahwa Indonesia ialah negara yang berdasar atas hukum (Rechtsstaat), hal ini menunjukan bahwa Indonesia tidak berdasarkan pada kekuasaan semata (machtsstaat) tetapi berdasarkan atas hukum. Pengakuan tersebut dipertegas kembali pada Pasal 1 ayat (3) amandemen UUD NRI Tahun 1945 yang menyatakan bahwa Negara Indonesia adalah negara hukum. Berdasarkan ketentuan Konstitusi tersebut, maka negara Indonesia diperintah berdasarkan hukum yang berlaku, termasuk penguasa pun harus tunduk pada hukum yang berlaku tersebut.

Menurut Sudikno Mertokusumo, hukum itu bukan merupakan tujuan, tetapi sarana atau alat untuk mencapai tujuan yang sifatnya non yuridis, dan berkembang karena rangsangan dari luar hukum, sehingga membuat hukum bersifat dinamis.

Menurut Soekarno Aburaera dkk, bahwa hukum dapat dilihat sebagai hukum positif yaitu hukum yang berlaku di dalam sebuah negara. Dalam konteks tersebut, hukum merupakan penetapan oleh pemimpin yang sah dalam suatu negara sebagaimana juga yang dimaknai oleh 
para ahli hukum. Hal ini sejalan dengan pandangan Austin yang menyatakan bahwa hukum merupakan perintah dari yang berdaulat.

Sementara itu, dalam pandangan masyarakat biasa, hukum dikonstruksikan sebagai suatu kehidupan bersama dalam masyarakat yang diatur secara adil. Jadi, nilai-nilai keadilan dalam hukum yang dipandang sebagai norma yang lebih tinggi dibandingkan dengan norma hukum dalam suatu undang-undang.

Berbagai pandangan tersebut menunjukan bahwa keberadaan hukum didasari oleh semanagat ideal untuk mewujudkan keadilan bagi masyarakat, untuk itulah maka pemerintah sebagai pembentuk hukum harus dapat menerjemahkan nilai-nilai keadilan setiap produk hukum yang dibentuk.

Hal tersebut jika dikaitkan dengan pandangan Satjipto Rahardjo, maka titik temunya adalah bagaimana membuat hukum dapat memberikan kebahagiaan (keadilan) bagi rakyat dalam suatu konsep hukum untuk manusia. Dimana, hukum tidak hanya dilihat sebagai bangunan peraturan perundang-undangan sebagai produk atau perintah penguasa semata, tetapi hukum harus dibuat ibarat suatu organis yang mampu berpikir, merencanakan dan sekaligus bertindak sesuai dengan hati nuraninya yang dilandasi pada nilai-nilai keadilan dalam masyarakat untuk mewujudkan kebahagiaan rakyat secara menyeluruh.

Keberadaan hukum untuk memberikan kebagahagian dalam pandangan Satjipto Rahardjo tidak hanya sebatas merumuskan hukum yang adil semata, tetapi hukum harus juga menjadi sarana untuk mempengaruhi atau mengubah masyarakat agar dapat mewujudkan keinginan hukum itu sendiri. Untuk itu, dibutuhkan ketersediaan hukum dalam arti kaidah atau peraturan, melainkan juga adanya jaminan penegakan hukum (law enforcement) yang baik, hal ini menunjukan bahwa agar kepentingan manusia terlindungi, hukum harus dilaksanakan dengan kata lain hukum yang dilanggar harus ditegakkan, melalui penegakkan hukum inilah hukum menjadi kenyataan. Menurut Secsio Jimec Nainggolan yang mengutip pandangan Achmad Ali bahwa bekerjanya hukum bukan hanya merupakan fungsi perundang- undangannya belaka, melainkan aktifitas birokrasi pelaksananya.

Teori sistem hukum oleh Lawrence M. Friedman menyebutkan bahwa sistem hukum terdiri atas perangkat struktur hukum, substansi hukum (perundang-undangan) dan kultur hukum atau budaya hukum, ketiga komponen ini mendukung berjalannya sistem hukum disuatu negara.

Terkait dengan konteks pelaksanaan dan penegakan aturan PSBB di Kota Ambon sangat dipengaruhi oleh struktur hukum yang keliru dalam menegakan aturan yang berlaku oleh aparat penegak hukum, seperti adanya larangan aktifitas pedagang di Ambon Plaza, padahal sesuai Perwali PSBB Kota Ambon bahwa aktifitas pertokoan dan mall dimulai pukul 08.00-20.00 WIT.

Masalah Substansi hukum, yang terkait dengan apa saja yang dihasilkan oleh institusi pembentuk hukum yang tidak cermat dalam merumuskan aturan tentang sanksi bagi yang berbocengan motor dan tidak menggunakan masker. Serta masalah kultur hukum, yang terkait dengan perilaku masyarakat yang masih tidak taat terhadap aturan PSBB, sebagaimana yang telah diuraikan sebelumnya. 
Dalam kaitan dengan hal tersebut maka persoalan substansi hukum, struktur hukum maupun budaya hukum yang harus dtitingkatkan kualitasnya agar berpengaruh terhadap efektivitas pelaksanaan aturan PSBB di Kota ambon, sehingga keberadaan perwalikota ambon tentang PSBB dapat memberikan perlindungan bagi masyarakat di masa pandemi covid 19

Secara substansi telah dilakukan beberap perubahan terkait dengan materi muatan Peraturan Walikota Ambon Nomor 18 Tahun 2020 Tentang Pelaksanaan Pembatasan Sosial Berskala Besar Dalam Penanganan Corona Virus Disease 2019 (COVID-19) di Kota Ambon, dengan Peraturan Walikota (Perwali) Nomor 19 Tahun 2020 tentang Perubahan atas Peraturan Walikota Ambon Nomor 18 Tahun 2020 Tentang Pelaksanaan Pembatasan Sosial Berskala Besar Dalam Penanganan Corona Virus Disease 2019 (COVID-19) di Kota Ambon, pada tanggal 6 Juli 2020, akan tetapi perubahan tersebut belum cukup maksimal dalam memberikan perlindungan bagi masyarakat tetapi sebaliknya dapat menimbulkan maslah baru dalam penegakannnya.

Hal tersebut dapat dilihat dalam Pasal 36 Perwali Nomor 19 Tahun 2020 tentang Perubahan atas Peraturan Walikota Ambon Nomor 18 Tahun 2020 Tentang Pelaksanaan Pembatasan Sosial Berskala Besar Dalam Penanganan Corona Virus Disease 2019 (COVID-19) di Kota Ambon yang mengatur tentang diberikan akses bagi aktivitas jual beli di pasar tradisional yang menjual kebutuhan sehari-hari dengan waktu operasional jam 05.30-18.00WIT, sementara itu, pusat perbelanjaan (mall) ditutup.

Pengaturan tersebut dalam implementasinya akan sulit memberikan dukungan terhadap perlindungan masyarakat di dalam berkatifitas, mengingat aktivitas masyarakat di pasar tradisional sangat sulit diawasi jika tidak ditunjang dengan keberadaan aparat penegak hukum yang memadahi, sehingga kewajiban masyarakat selama pemberlakukan PSBB sulit untuk diwujudkan seperti adanya pemaikan masker dan adanya jaga jarak diantara masyarakat selama beraktivitas di pasar tradisional. Sebaliknya, aktivitas masyarakat di pusat perbelanjaan agak lebih mudah diawasi mengingat tersedia sarana penunjang dan sumberdaya yang dimiliki oleh pusat-pusat perbelanjaan dalam mengawasi pelaksanaan protocol kesehatan.

Selain itu, pengaturan dalam penggunaan saran transportasi baik sarana transportasi umum maupun pribadi hanya difokuskan pada proses penegakannya tetapi tidak disertai dengan tindakan pencegahan. Hal ini dapat dilihat dalam Pasal 47 Peraturan Walikota Ambon Nomor 18 Tahun 2020 Tentang Pelaksanaan Pembatasan Sosial Berskala Besar Dalam Penanganan Corona Virus Disease 2019 (COVID-19) di Kota Ambon yang mengatur mengenai pembatasan penumpang, pembatasan jam operasional dan pembagian waktu operasional angkutan umum, sedangkan tidak diatur mengenai transportasi pribadi. Setelah dilakukan perubahan melalui Peraturan Walikota (Perwali) Nomor 19 Tahun 2020 pengaturan mengenai sarana transportasi juga mengatur mengenai transportasi pribadi pada Pasal 53A yang mengatur bahwa angkutan orang dengan kendaraan pribadi dilakukan dengan sistem ganjil genap, yaitu berdasarkan angka akhir plat nomor.

Kedua pengaturan tersebut tidak memberikan ruang pencegahan melalui mekanisme sterilisasi terhadap sarana transportasi, baik transportasi umum maupun transportasi pribadi baik 
dilakukan oleh pemerintah maupun dilakukan secara mandiri oleh masyarakat. Secara khusu terhadap angkutan umum sebaiknya disediakan mekanisme sterilisasi yang dilakukan oleh pemerintah sebagai mekanisme pencegahan dalam penangan penyebaran virus covid 19 saat berlakunya PSBB.

Selain itu, berbagai aktivitas pengawasan dilakukan hanya untuk menegakan tanpa ada mekanisme pencegahan yang terapkan oleh pemkot Ambon seperti adanya berbagai razia di jalan umum untuk memberikan sanksi bagi setiap pengendara kendaraan yang tidak menggunakan masker, atau menaikan penumpang yang tidak sesuai dengan aturan PSBB, tetapi tidak ada mekansime pencegahan seperti penyiapan dan pembagian masker bagi masyarakat yang tidak menggunakan masker, selain pengenaan denda.

Berbagai hal tersebut memberikan dampak terhadap upaya penegakan hukum dan perilaku masyarakat yang tidak taat terhadap aturan tentang PSBB yang sering dilanggar oleh masyarakat. Keadaan ini membuat upaya perlindungan hukum yang tidak maksimal dalam penyelenggaraan PSBB di Kota Ambon.

Menurut Lili Rasjidi dan I.B Wysa Putra bahwa hukum dapat keberadaan hukum dapat berfungsi dengan baik bukan hanya untuk dalam memberikan perlindungan yang adaptif dan fleksibel, tetapi juga prediktif dan antisipatif.

Hal ini menunjukan bahwa perlindungan hukum tidak hanya dilakukan untuk menghindari kondisi yang dapat merugikan kepentingan seseorang, tetapi perlindungan juga dilakukan dengan dapat mencegah terjadinya situasi atau kondisi yang dapat merugikan kepentingan seseorang.

Philipus M. Hadjon mengatakan bahwa, terdapat 2 (dua) macam perlindungan hukum yaitu, "perlindungan hukum preventif dan perlindungan hukum represif. perlindungan hukum yang preventif terkait dengan keberadaan hukum untuk mencegah terjadinya sengketa, sementara itu perlindungan hukum represif merupakan mekanisme untuk menyelesaikan sengketa.

Berdasarkan pandangan tersebut maka keberadaan aturan PSBB melalui Perwali kota ambon tentang PSBB dibuat bukan hanya untuk memberikan perlindungan hukum secara represif, yaitu jika telah terjadi pelanggaran maka aturannya ditegakan, tetapi juga diharapkan dapat mengatur berbagai hal yang sifatnya preventif, yaitu terdapat pengaturan mengenai berbagai hal yang berfungsi mencegah agar tidak terjadi pelanggaran hukum yang terkait dengan pelaksanaan PSBB di kota ambon

\section{PENUTUP}

Berdasarkan hasil penelitian, maka kesimpulan yang dapat disampaikan adalah:

1. Efektivitas PSBB di kota ambon belum dilkasanakan secara maksimal.

2. perlindungan hukum bagi masyarakat kota ambon lebih difokuskan pada uapaya penegakan (represif) dibandingkan dengan upaya pencegahan preventif. 


\section{DAFTAR PUSTAKA}

Achmad Ali, 2005, Keterpurukan Hukum di Indonesia, Cetakan kedua, Ghalia Indonesia, Bogor,

Achmad Ali, 2009, Menguak Teori Hukum (legal Theory) \& Teori Peradilan (Judicialprudence): Termasuk Interpretasi Undang-undang (Legisprudence), Kencana

Anthonius Cahyadi dan fernando Manullang, 2010, Pengantar ke Filsafat Hukum, Kencana, Jakarta

Lili Rasjidi dan I.B Wysa Putra, Hukum Sebagai Suatu Sistem, Remaja Rusdakarya, Bandung 1993

Luthvi Febryka Nola, Upaya Pelindungan Hukum Secara Terpadu Bagi Tenaga Kerja Indonesia (TKI), Negara Hukum: Vol. 7, No. 1, Juni 2016

Munir Fuady, Aliran Hukum Kritis : Paradigma Ketidakberdayaan Hukum, PT. Citra Aditya Bakti, Bandung

Peter Mahmud Marzuki, 2005, Penelitian Hukum, Prenada Media, Cet. I, Jakarta

Philipus M. Hadjon dkk, 2011, Pengantar Hukum Administrasi Indonesia, Gajah Mada University Press, Yogyakarta

Philipus M Hadjon, Pengkajian Ilmu Dogmatik (Normatif), Fakultas Hukum Universitas Airlangga, Surabaya, 1994

Satjipto Rahardjo, 1991, Ilmu Hukum, PT Citra Aditya Bakti, Bandung Satjipto Raharjo, 2000, Ilmu Hukum, Bandung: PT. Citra Aditya Bakti,

Satjipto Rahardjo, 2009, Negara Hukum Yang Membahagiakan Rakyatnya, Gentha Publishing, Yogyakarta

Setiono, Rule Of Law (supremasi hukum), Magister Ilmu Hukum Program Pascasarjana Universitas Sebelas Maret, Surakarta, 2004

Soerjono Soekanto, 1983, Beberapa Permasalahan Hukum Dalam Kerangka Pembangunan di Indonesia, UI Press, Jakarta

Soerjono Soekanto, 2010, Faktor-faktor yang Mempengaruhi Penegakan Hukum, Rajawali Pres, Jakarta

Sudikno Mertokusumo, 1993, Bab-Bab Tentang Penemuan Hukum, PT Citra Aditya Bakti, Bandung

Sukarno Aburaera dkk, 2009, Filsafat Hukum, Bayumedia Publishing, Malang

Secsio Jimec Nainggolan, Analisis Yuridis Penentuan Kedudukan Saksi Pelaku Sebagai Justice Collaborators Dalam Tindak Pidana Narkotika Di Pengadilan Negeri Pematang Siantar (Studi Putusan No: 231/Pid.Sus/2015/Pn), USU Law Journal, Vol.5.No.3 (Oktober 2017),

Evi Deliana Hz, Perlindungan Hukum Terhadap Anak Dari Konten Berbahaya Dalam Media Cetak Dan Elektronik, Jurnal Ilmu Hukum, Volume 3 No. 1 < https://media.neliti.com/media/publications/9138-ID-perlindungan-hukum- terhadapanak-dari-konten-berbahaya-dalam-media-cetak-dan-ele.pdf

<https://www.amnesty.id/covid-19-dan-hak-asasi-manusia/>, diakses tanggal 30 mei 2020 
https://www.kabartimurnews.com/2020/06/29/pedagang-pakaian-minta-penerapan- psbb-adil/>, diakses tanggal 16-7-2020

https://www.gatra.com/detail/news/483611/ekonomi/penerapan-perwali-psbb-ambon- dinilaimasih-banyak-kelemahan diakses tanggal 1 November 2020`

https://regional.kompas.com/read/2020/07/01/20164911/banyak-warga-langgar- $\quad$ protokolkesehatan-psbb-ambon-akan-dievaluasi?page=all, diakses tanggal 5 November 2020

https://rri.co.id/ambon/daerah/857848/penerapan-perwali-psbb-di-kota-ambon-tak- $\quad \underline{\text { sesuai- }}$ pelaksanaan, diakses tanggal 10 November 2020

https://regional.kompas.com/read/2020/04/28/21023121/alasan-pemkot-ambon- ajukan-psbbbutuh-landasan-hukum-tindak-tegas-pelanggar?page=all., diakses tanggal 10 November 2020 